\title{
The Performance of School Supervision Organizations in the Remote Area of East Aceh Regency
}

\author{
Nurdin ${ }^{1,2} *$ Sumin $^{3}$, Venny Hidayat ${ }^{1}$ \\ ${ }^{1}$ Educational Research and Evaluation Study Program, Universitas Negeri Yogyakarta, Indonesia \\ ${ }^{2}$ Dinas Pendidikan Aceh, Indonesia \\ ${ }^{3}$ IAIN Pontianak, Indonesia \\ *Corresponding author. Email: nurdin.2021@student.uny.ac.id
}

\begin{abstract}
The performance of school supervision organizations in the remote area in East Aceh regency faces many problems. The constraints include the geographic condition and other conditions such as the insufficient number of the school supervisors, low qualification and competence of the school supervisors, and the composition of the school supervisors are still not ideal. The research was conducted to analyze the performance of the school supervision organization in the East Aceh regency and to describe the factors that influenced the works of school supervision organizations in East Aceh to produce an effective supervision system. The measurement of the organization's performance can be done by using 7S McKinsey Framework, which has seven variables/factors: share value, strategy, structure, system, skill, staff, and leadership styles. The approach that was used in this research is qualitative. The data collection was done through interviews, observation, and document study. The informants in this research were: The Head of Higher Education Department, School Supervisors Coordinator and Higher School Supervisors within the Educational office of East Aceh, the principal of SMP (Junior High School) and SMA (Senior High School), teachers, and the head of LPMP (Education Quality Guarantee Institution) of Aceh province. The data collection was done within five months, from February to June 2013. The result of the research shows that only two factors of 7S McKinsey qualify; they are share value and style of leadership. Meanwhile, the others are not qualified.
\end{abstract}

Keywords: mckinsey framework, supervision organization, performance, remote area

\section{INTRODUCTION}

The purpose of providing education in Indonesia is stated in [1], Article (2) states that "National education functions to develop capabilities and shape the character and civilization of a dignified nation in the context of educating the nation's life, aiming at developing the potential of students to become human beings who believe and fear God Almighty, have noble character, are healthy, knowledgeable, capable, creative, independent, and become a democratic and responsible citizen". The success of the implementation of formal education to achieve national education goals as mandated by the Law on the National Education System is determined by several factors, including Principals, Teachers, Students, School Administration Officers, and School Supervisors. Without underestimating the role of other factors, the supervisor's position is at the most strategic level. Their role is specified in [2] Article (55) states that "supervision of education units (schools) includes monitoring, managerial supervision, academic supervision carried out regularly and continuously by supervisors or supervisors of educational units and heads of education units."

The activities of school supervisors in carrying out school supervisory duties in their target schools are by the level of the school supervisor's position. Based on [3] Article (13) Paragraph (1) states that "The functional level of the School Supervisor from the lowest to the highest, namely: Junior School Superintendent, Middle School Supervisor, and Main School Superintendent."

East Aceh Regency, located in the eastern part of Aceh Province, consists of 24 sub-districts. Of the 24 sub-districts in East Aceh, four sub-districts are in the 3T (Rural, Remote, Isolated) area category, the highest 
(100\%) there are four sub-districts: Simpang Jernih, Serbajadi, Peunaron, and Indramakmu sub-districts [4].

The number of secondary schools in East Aceh, SMP, SMA, and SMK in 2010 totaled 114 schools. It consists of 20 SMA, 7 SMK, and 87 public and private junior high schools [4]. Based on the school supervisor's annual report, at the secondary level of the East Aceh District Education Office, it was found that only $25 \%$ of schools had a school development program with their supervisors. These schools are located in easily accessible urban areas. It means that there are problems with the activities of school supervisors in the 3T (rural, remote, and isolated) area.

Dalman Drajat researched supervision in 2009 with the problem of research on how to empower school supervisors in Bekasi City. Conclusions and Recommendations resulting from this study are that there are still several problems that hinder the performance of school supervisors. These problems include systems, skills, staff, and supervisory strategies..

As reported in Dalman Drajat's research, supervision problems can be found in East Aceh District. Therefore, the authors are motivated to uncover the current performance of the school supervisory organization in East Aceh Regency and what factors influence the performance of the school supervision organization in East Aceh Regency to produce an effective supervision system. The analysis tool using the 7-S McKinsey Framework from management consultancy McKinsey and Company which was developed by the authors, namely Thomas J. Peters and Robert H. Waterman Jr. in his book "In Search of Excellence": lessons from America's Best-Run Companies, New York: Harper Collins, 1997.

The 7S McKinsey Framework can be used to unify practical organizational elements to improve organizational performance. This framework can also be applied to almost any organization.

\section{METHOD}

The study applied a qualitative approach to get a picture close to the natural conditions. The focus of the research was to seek the performance of school supervision organizations in the $3 \mathrm{~T}$ area of East Aceh Regency and find the factors that influenced the implementation of school supervision organizations to produce an effective supervision system. The research was carried out for five months, starting from February to June 2013. The object of research in this study is the organization and individual of the school supervision in East Aceh Regency.

This research is designed to provide a systematic, factual, and accurate description of the facts, characteristics, and relationships between the investigated phenomena, so the level of analysis of this study is descriptive. This study uses two types of data: primary and secondary data. The primary one was collected from the schools, supervisory organizations, East Aceh District Education Office, and LPMP Aceh. Apart from interviews, primary data was also obtained through observation. To strengthen the data obtained through interviews and observations and test the integrity of the data, the researchers conducted a documentation study. Informants of this study are presented in Table 1.

Table 1. List of primary data source informants

\begin{tabular}{|l|l|l|}
\hline No. & \multicolumn{1}{|c|}{ Data Source } & Amount \\
\hline 1. & $\begin{array}{l}\text { Head of Middle Education Division of the } \\
\text { Education Office of East Aceh Regency }\end{array}$ & 1 person \\
\hline 2. & $\begin{array}{l}\text { Principal of the 2nd Indra Makmu Junior } \\
\text { High School, East Aceh Regency }\end{array}$ & 1 person \\
\hline 3. & $\begin{array}{l}\text { Deputy Principal of SMP Negeri 2 Indra } \\
\text { Makmu, East Aceh Regency }\end{array}$ & 1 person \\
\hline 4. & $\begin{array}{l}\text { Teacher of SMP Negeri 2 Indra Makmu, } \\
\text { East Aceh Regency }\end{array}$ & 2 persons \\
\hline 5. & $\begin{array}{l}\text { Deputy Principal (Biology Teacher) for the } \\
\text { Curriculum Sector of SMA Negeri } 1 \\
\text { Peunaron, East Aceh Regency. }\end{array}$ & 1 person \\
\hline 6. & $\begin{array}{l}\text { Coordinator of School Superintendent for } \\
\text { East Aceh District Education Office }\end{array}$ & 1 person \\
\hline 7. & $\begin{array}{l}\text { Middle school superintendent of the East } \\
\text { Aceh District Education Office }\end{array}$ & 3 people \\
\hline 8. & $\begin{array}{l}\text { Head of LPMP Aceh Province } \\
\text { Number of informants }\end{array}$ & 1 person \\
\hline
\end{tabular}

The primary data collection technique was through interviews using data collection tools in the form of interview guidelines and observation with data collection tools in the form of observation sheets. At the same time, the secondary data was obtained through the study of documentation using data collection tools in the form of records of documentation analysis.

The triangulation technique carried out data validation. Data obtained from teachers of SMP Negeri 2 Indra Makmu was compared with data from teachers of SMA Negeri 1 Peunaron. It could enrich while validating whether the data obtained is close to the fact or not. Likewise, the comparison also is made for data from the Principal of SMP Negeri 2 Indra Makmu and the Principal of SMA Negeri 1 Peunaron. Since the Principal of SMA Negeri 1 Peunaron is in the switching 
process, the principal's informant was then switched to the Deputy Principal for Curriculum.

The supervisory performance data obtained from two schools, namely SMP Negeri 2 Indra Makmu and SMA Negeri 1 Peunaron, were then compared with the researchers' interviews with school supervisors. Validation was also carried out with the researcher's interview with the Head of the Secondary Education Division of the East Aceh District Education Office. To obtain a complete picture of the strategy for implementing school supervision, especially secondary schools in East Aceh Regency, the researcher also conducted validation by interviewing the Aceh Province Education Quality Assurance Institute (LPMP).

The researcher carried out data validation by time triangulation to ensure the triangulation process. School visits to collect the data were carried out two times, while the East Aceh District Education Office visits were carried out six times.

The researchers also conducted data collection techniques triangulation to ensure high validity data. Data obtained through interviews will be cross-checked with observations and documentation studies. Data analysis was performed using an interactive analysis model [5]. This analysis is done in three steps, namely:

\subsection{Data Reduction}

The various interview results from all informants were then classified based on their similarities. The tool to dissect the results of the interviews in this study was the 7-S McKinsey Framework concept. Themes are classified in essential order under McKinsey's 7-S variables and raise a pattern related to developing school supervision. At the same time, the things that are not necessary will be discarded or ignored.

\subsection{Data Presentation}

In this study, researchers present more data in narrative text. However, there is still data presented in tables and charts or pictures.

\subsection{Drawing conclusions / Verification}

Conclusions were developed to answer research questions about the current performance of school supervisory organizations in the $3 \mathrm{~T}$ area in East Aceh District. The recommendations or suggestions about what efforts should be made by all parties to create better school supervision activities in East Aceh Regency then were proposed.

\section{FINDINGS AND DISCUSSIONS}

The results of research on the performance of school supervisory organizations in East Aceh Regency and what factors affect the performance of school supervisory organizations are presented following what is conveyed in The McKinsey 7S Framework, which consists of seven elements (aspects), namely: shared values, structure, systems, strategy, skills, staff, and style of leadership. [6]

\subsection{Shared values}

In carrying out supervisory duties, the Middle School Superintendent of the East Aceh District Education Office already has a vision and mission. The vision and mission of the school supervisors of the Education Office of East Aceh Regency have not been revised since 2008. There has never been a meeting in the form of a work meeting for school supervisors, especially the Secondary Education Supervisor, which was conducted to evaluate the implementation of the vision and mission of supervision since 2008. Based on the results and discussion of the above-shared value factor, it can be concluded that the supervisory organization has fulfilled the shared value factor in East Aceh Regency.

\subsection{Structure}

The structure of an organization is depicted on a map or organizational chart (organigram, organization chart). This organizational scheme provides an overview of the overall activities and processes that occur in an organization. The organizational structure has several meanings for the organization, one of which is to describe reporting relationships expressed by vertical lines [7].

Based on the organizational structure of the East Aceh District Education Office, it is clear what is the position of school supervisors. However, in reality, the Strategic Plan of the Aceh District Education Office Timur in 2009 did not discuss supervisors' primary duties and functions. According to the Head of Dikmen at the Education Office of East Aceh Regency, the discussion on the description of supervisory duties was not included in the 2009 Strategic Plan of the Service (Head of Dikmen, 1 June 2013). Suppose the school supervisor is indeed part of this organizational structure. In that case, there should be a discussion of the supervisor's primary duties and functions in the Education Office's strategic plan.

Supervisors are not an internal part of the school. The school places the principal as the vertical peak; it indicates that the highest command in the education unit is the principal. The principal is the manager and leader of the school organization. Based on this vertical relationship, it is understandable that the principal's voice will be heard and obeyed by teachers and administrative staff. School supervisors who carry out 
supervisory duties at the target schools are still considered guests with authority to give small orders. No matter how good supervisors carry out the activities in the schools, the final results or their implementation depend on the principal's performance.

It will be easier if the school supervisor is in the school organizational structure or becomes an internal party to the school. The existence of supervisors who are outside the school organizational structure does require good school supervisor communication skills. Glickman conveyed that one of the technical skills that school supervisors must possess is communication techniques [8]. It is recognized that many teachers in the schools think that the school supervisor comes to meet the principal and not to meet the teacher. This condition happened because, from the beginning, the school supervisor had not been prepared to become a professional school supervisor, understanding his primary duties and functions. Different circumstances are accepted by supervisors who have good supervisory competence. Instead, the teachers felt happy and always expected the supervisor to come to their school without fear.

\subsection{System}

Based on observations at the East Aceh District Education Office and interviews with three school supervisors, several notes can be written for the analysis of system variables in the school supervisory organization:

a) Determination of target schools for each school supervisor has not been carried out based on environmental analysis and school supervisor competencies.

b) Oral reprimands are usually given to supervisors who rarely or never attend the morning assembly.

c) The monthly report submitted by the school supervisor to the head of the education office, as the direct supervisor of the school supervisor, is still only an administrative report. The report submitted has not touched the content of the supervision

d) The existence of attendance regulations to the education office every working day has made the supervisor's routine resemble the routine of the office's structural employees in terms of working hours.

e) The length (time) of the assignment is too short. In short, the supervisory assignment time to foster one target school and the absence of communication between the old supervisor and the substitute supervisor resulted in the non-running of the supervisory program at the school on an ongoing basis. Indeed, many things can be done, but the programs that can be run are only short-term and not sustainable. The average tenure of school supervisors at their target schools is two years. Some have not carried out their duties as school supervisors for two years but have been transferred to become school principals.

\subsection{Strategy}

The analysis results of supervisory documents have not found any formulation of a supervisory strategy in school supervisory organizations in East Aceh Regency. Organizations without a clear strategy find it difficult to justify the reasons for their existence and continue to draw on the resources they need to survive. Strategy is not just a written document. Strategy is a way of thinking about how an organization works [9].

\subsection{Skills}

No school supervisor has competence at an advanced level. It appears to impact the implementation of school supervision that has not been innovative. The performance of school supervision is only limited to fulfilling essential duties as supervisors to meet the requirements for obtaining the school supervisor's functional allowance.

\subsection{Staff}

The average working period as a school supervisor is two years. This relatively short period of work as a school supervisor implements providing professional assistance from school supervisors to school principals, teachers, and school administrative staff not run optimally. The programs that can be run are only shortterm programs in the form of monitoring or monitoring routine activities, such as national exam activities, new student admissions, class promotions, socialization of official programs or programs from the Central Government.

\subsection{Style of leadership}

A Superintendent Coordinator leads the secondary school supervisor. The current Korwas leadership was appointed in 2008. Based on a discussion with the secondary education supervisor of the East Aceh District Education Office on January 2, 2013, all school supervisors $(100 \%)$ stated that they were still satisfied with Korwas' leadership style. The reason is that what the school supervisors do gets good support from the Korwas. The most tangible forms of support are 1) operational cost assistance from the East Aceh District Education Office, 2) two-wheeled vehicle assistance for school supervisors as many as 39 units, and 3) providing 
workspaces. for supervisors who previously did not have an office.

\section{CONCLUSION}

Based on the results and discussion, the conclusions of this study are as follows. (1) The performance of the school supervisory organization in East Aceh Regency has not been running well. The indicators of the conclusion are: (a) There is no program for the appointment of school supervisors that refers to the needs of the target schools and the readiness of prospective school supervisors. (b) School supervisors do not yet have a strategic plan for secondary school supervision. (c) The implementation of supervision does not yet have a share value as an adhesive for school supervisors in providing professional assistance and the vision and mission. (d) In terms of organizational structure, the supervisory position is not clear. (e) System or the reporting mechanism is still limited to meeting the administrative requirements for supervision, not yet focusing on the supervisory material provided. (f) There is no certainty about the length of time the supervisor will be assigned in one target school. (g) There is a lack of competency improvement training for supervisors, junior supervisors, middle supervisors, and principal supervisors. (h) The position of coordinator of school supervisors has not played a leading role. (i) The performance of school supervisors has not been assessed professionally. (j) There is no reward and punishment system yet.

In addition, (2) the factors that influence the performance of the school supervisory organization in East Aceh Regency to produce an effective supervision system there are five factors from the 7S McKinsey Framework that have not been met, namely: (a) Staff or quality of human resources for school supervisors, especially academic qualifications and subject backgrounds; (b) skills, especially on the ability to carry out academic supervision/supervision; (c) System Supervision has not connected the needs of the target schools with the performance of the school supervisory organization and the carrying capacity of the Education Office correctly. (d) The strategy must be related to the overall planning of supervisory activities, including assigning supervisors to the target schools according to the capacity of school supervisors, performance appraisal, and giving rewards and punishments. (e) The position of school supervisors in the structure of the Education Office and schools must be clarified to make it easier for supervisors to carry out supervision. In addition to these five factors, support from other institutions that serve as supervisors is needed, such as the Education Quality Assurance Institute (LPMP).

\section{AUTHORS' CONTRIBUTIONS}

Author 1, 3 and 4 wrote the manuscript in consultation. All authors discussed the results and contributed to the final manuscript.

\section{ACKNOWLEDGMENTS}

This paper and the reaserach it would not have been possible without the exceptional support from Aceh Province Human Resources Development Institute (BPSDM) and Doctoral Program of Educational Reasearch and Evalutation, Yogyakarta State University.

\section{REFERENCES}

[1] Kemendikbud RI, "UU No.20 Tahun 2003 Tentang Sistem Pendidikan Nasional,”. 2003, Jakarta, Jakarta, Indonesia.

[2] Pemerintah Republik Indonesia, "Peraturan Pemerintah Nomor 19 Tentang Standar Nasional Pendidikan,”. 2005, Jakarta, Indoensia.

[3] Permeneg PAN-RB, "Permeneg PAN-RB Nomor 21 Tentang Jabatan Pengawas Sekolah dan Angka Kreditnya,”, 2010, Jakarta.

[4] Badan Pusat Statistik Kabupaten Aceh Timur, "Kabupaten Aceh Timur dalam angka 2010,". 2010, Aceh Timur,.

[5] M. B. A. M. H. Miles, Qualitative data anlysis, Second Edi. 1994, California: Sage Publication, Inc.

[6] J. Thomas J. Perters and Robert H. Waterman, In Serach of Excellence (Lessons from America's Best-Run Companies. 1997, Maine-USA: G.K. Hall and Co Thorndike.

[7] M. Lubis, Hari dan Huseini, Teori Organisasi (Suatu Pendekatan Makro). 2009, Jakarta: FISIP UI.

[8] Glickman, Instructional Supervision. 1985, New Jersey: Prentice Hall, Inc Englewood Cliftfs.

[9] T. Cohen, Steven., Eimicke, William., dan Hikkila, The Effective Public Manajer, 2011, Versi Baha. PPM-Jakarta. 